\title{
Jurnal Riset Akuntansi dan Bisnis
}

Vol . 20, No. 1, 2020, hal. 23-37

ISSN 1693-7597 (Print), 2623-2650 (online)

Available online: http://jurnal.umsu.ac.id/index.php/akuntan

\section{Analisis Determinan Minat Mahasiswa Dalam Menggunakan Lembaga Keuangan Syariah}

\section{Soulthan Saladin Batubara}

Fakultas Sosial Sains

Universitas Pembangunan Panca Budi

Jl. Jendral Gatot Subroto KM. 4,5 Sei Sikambing 20122 Medan - Sumatera Utara-Indonesia

Korespondensi: soulthanbatubara@dosen.pancabudi.ac.id

\section{Delyana Rahmawany Pulungan}

Fakultas Ekonomi dan Bisnis

Universitas Muhammadiyah Sumatera Utara

Jl. Kapten Mukhtar Basri No. 3 Telp. (061) 6624567 Medan 20238

\author{
Musfa Yenty \\ Program Studi Manajemen \\ Fakultas Ekonomi dan Bisnis \\ Universitas Muhammadiyah Sumatera Utara \\ Jl. Kapten Mukhtar Basri No. 3 Telp. (061) 6624567 Medan 20238
}

DOI: https://doi.org/10.30596/ jrab.v20i1.4757

\begin{abstract}
Abstrak: Literasi Keuangan dan inklusi keuangan menjadi faktor pendorong bagi perkembangan lembaga keuangan syariah saat ini. Adanya kebutuhan masyarakat yang semakin kompleks, tidak hanya masyarakat umum saja yang menggunakan lembaga keuangan syariah, tetapi kalangan anak muda juga sudah harus menggunakan produk lembaga keuangan syariah. Penelitian ini mengunakan pendekatan kuantitatif dengan jenis penelitian asossiatif. Penelitian ini dilakukan pada mahasiswa Ekonomi dan Bisnis jurusan Manajemen Universitas Muhammadiyah Sumatera Utara Semester 6 (enam). Sampel yang diambil dalam penelitian ini sebanyak 100 orang. Teknik pengumpulan data dalam penelitian ini dengan metode kuisioner, dokumentasi dan wawancara kepada responden. Hasil penelitian menunjukkan bahwa Literasi keuangan berpengaruh positif dan signifikan terhadap minat mahasiswa dalam menggunakan lembaga keuangan syariah, inklusi berpengaruh positif dan signifikan terhadap minat mahasiswa dalam menggunakan lembaga keuangan syariah. Literasi keuangan dan inklusi keuangan secara simultan memiliki pengaruh positif dan signifikan terhadap minat mahasiswa dalam menggunakan lembaga keuangan syariah.
\end{abstract}

\begin{abstract}
Financial Literacy and financial inclusion are the driving factors for the development of Islamic financial institutions today. The existence of increasingly complex community needs, not only the general public who use Islamic financial institutions, but also young people must use the products of Islamic financial institutions. This study uses a quantitative approach to the type of associative research. This research was conducted on Economics and Business students majoring in Management at the University of Muhammadiyah North Sumatra Semester 6 (six). Samples taken in this study were 100 people. Data collection techniques in this study were questionnaire, documentation and interview methods for respondents. The results showed that financial literacy had a positive and significant effect on students 'interest in using Islamic financial institutions, inclusion had a positive and significant effect on students' interest in using Islamic financial institutions. Financial literacy and financial inclusion simultaneously have a positive and significant influence on students' interest in using Islamic financial institutions.
\end{abstract}

Keywords: Financial Literacy, Financial Inclusion, Student Interest, Islamic Financial Institutions

Cara Sitasi : Batubara S.S., Pulungan, Delyana R. (2020). Analisis Determinan Minat Mahasiswa dalam Menggunakan Lembaga Keuangan Syariah. Jurnal Riset Akuntansi dan Bisnis, 20(1), 23-37 https://doi.org/10.30596/irab.v19i2.4757 


\section{Jurnal Riset Akuntansi dan Bisnis}

Vol . 20, No. 1, 2020, hal. 23-37

ISSN 1693-7597 (Print), 2623-2650 (online)

Available online: http://jurnal.umsu.ac.id/index.php/akuntan

Khusna (2018) menjelaskan bahwa pengetahuan masyarakat mengenai keuangan syariah semakin berkembang seiring dengan bertambahnya kebutuhan manusia yang semakin kompleks. Pengetahuan yang dimiliki sangat berguna untuk bersikap efektif demi terwujudnya kesejahteraan masyarakat yang berkaitan dengan globalisasi yang tidak dapat kita hindari, misalnya dalam hal menentukan keputusan masa depan yang berkaitan dengan keputusan jangka pendek ataupun jangka panjang terutama dalam mengelola keuangannya.

Menurut Krishna, dkk (2010) Literasi keuangan sangat berkaitan dengan kesejahteraan seorang individu. Pengetahuan keuangan dan keterampilan dalam mengelola keuangan pribadi sangat penting dalam kehidupan sehari-hari. Literasi keuangan membantu individu agar terhindar dari masalah keuangan. Kesulitan keuangan bukan hanya fungsi dari pendapatan namun juga muncul jika terjadi kesalahan dalam pengelolaan keuangannya.

Mahasiswa sebagai generasi muda sejak dini harus memiliki pengetahuan dibidang personal finance karena pengetahuan tersebut akan membantu mahasiswa dalam mengaturkeuangannya dimasa depan. Bagi mahasiswa mempelajari tentang pengelolaan keuangan produk serta layanan jasa keuangan merupakan hal yang mudah apalagi di era globalisasi yang semakin canggih seperti sekarang ini. Mahasiswa dapat dengan mudah mengakses tentang pengetahuan akan literasi keuangan di internet maupun dari berbagai sumber lainnya. Setelah literasi sudah dimiliki pada generasi muda, mereka juga diharapkan dapat memiliki keyakinan terhadap lembaga jasa keuangan serta produk dan layanannya. Namun pada kenyataannya masih banyak mahasiswa yang enggan bahkan tidak mau tau tentang bagaimana cara agar mereka dapat mengelola keuangannya dengan baik. Atau dengan kata lain, banyak mahasiswa yang tidak mau tau tentang apa tujuan dan manfaat literasi keuangan dalam mengelola keuangan mereka sendiri. Menurut Pulungan dan Febriaty (2018) menyatakan bahwa gaya hidup mahasiswa di jurusan Manajemen UMSU lebih cenderung hedonisme dan cukup mewah. Inilah yang menyebabkan mahasiswa memiliki literasi keuangan yang rendah.

Dalam Peraturan Presiden Republik Indonesia nomor 82 tahun 2016 tentang strategi nasional keuangan inklusif, Dalam rangka memperluas dan mempermudah masyarakat dalam mengakses layanan keuangan, diperlukan strategi khusus agar keuangan lebih inklusif. Keuangan inklusif adalah kondisi dimana setiap anggota masyarakat mempunyai akses terhadap layanan keuangan formal yang berkualitas secara tepat waktu, aman dan lancar dengan biaya terjangkau sesuai dengan kebutuhan dan kemampuan masyarakat.

Dalam Strategi Nasional Keuangan Inklusif (2016) Program SNKI ini bertujuan agar diharapkan seluruh masyarakat termasuk mahasiswa dapat dengan mudah dalam mengakses layanan lembaga jasa keuangan sesuai dengan kebutuhan. SNKI tidak hanya mempermudah akses lembaga keuangan konvensional saja namun juga lembaga keuangan syariah.

Namun fenomena yang saat ini terjadi pada mahasiswa ialah masih banyak kalangan mahasiswa yang belum mendapatkan akses akan layanan lembaga keuangan syariah. Rendahnya kesadaran mereka akan literasi keuangan menjadi faktor yang membuat mahasiswa belum menyadari keberadaan lembaga keuangan syariah yang ada disekitar mereka. Selain itu, masih kurangnya sosialisasi tentang produk dan layanan keuangan syariah bagi para mahasiswa. Faktor lain yang mempengaruhi mahasiswa enggan untuk mengakses layanan keuangan syariah adalah masih banyak mahasiswa yang berada pada kalangan ekonomi rendah sehingga mereka berfikiran untuk tidak menyentuh lembaga keuangan karena menurutnya keuangannya hanya cukup untuk biaya sehari-hari. 


\section{Jurnal Riset Akuntansi dan Bisnis \\ Vol . 20, No. 1, 2020, hal. 23-37 \\ ISSN 1693-7597 (Print), 2623-2650 (online) \\ Available online: http://jurnal.umsu.ac.id/index.php/akuntan}

Menurut pengamatan peneliti mahasiswa lebih tertarik dengan lembaga keuangan konvensional dikarenakan mereka sudah terbiasa dengan lembaga keuangan konvensional yang sudah lebih dulu merambah ke masyarakat bahkan mahasiswa sendiri dan juga konvensional selalu memberikan apresiasi terhadap nasabahnya seperti kegiatan pengundian hadiah sehingga banyak nasabah yang tertarik dengan lembaga keuangan konvensional. Kurangnya minat mahasiswa dalam menggunakan lembaga keuangan syariah disebabkan karena promosi akan produk-produk lembaga keuangan syariah masih kurang di kalangan mahasiswa dan juga pelayanannya belum setara dengan lembaga keuangan konvensional yang biasa mahasiswa gunakan. Lembaga keuangan syariah memang menggunakan sistem bagi hasil, dimana mungkin lebih baik dalam sistem keuntungan. Namun para mahasiswa belum banyak yang mengetahui akan produk-produk lembaga syariah sehingga lembaga keuangan syariah kalah saing dengan konvensional. Selain itu, lembaga keuangan konvensional juga lebih beragam karena mereka lebih kreatif dalam menciptakan produk-produk.

Menurut Khusna (2018) Keuangan inklusif merupakan salah satu instrumen yang menunjang literasi keuangan. Keuangan inklusif merupakan kemampuan perorangan dalam mengakses berbagai produk jasa keuangan yang terjangkau serta sesuai dengan kebutuhannya. Kemampuan ini utamanya berkaitan dengan pemahaman yang meliputi finansial awareness, pengetahuan tentang lembaga keuangan dan pengetahuan mengenai berbagai fasilitas yang disediakan lembaga keuangan serta permohonan atas berbagai keuntungan memanfaatkan saluran perbankan pemahaman tersebut masuk dalam indikator masyarakat yang telah well literate dalam bentuk literasi keuangan.

Kelompok pelajar, mahasiswa dan pemuda tentu mempunyai peran yang penting dalam mendukung peningkatan inklusi keuangan, karena merekalah generasi yang dianggap dapat meneruskan dan memajukan perekonomian.

\section{KAJIAN PUSTAKA \\ Literasi Keuangan}

Penggunaan produk atau jasa keuangan, dilakukan untuk memenuhi kebutuhan atau kepuasan individu dalam mengkonsumsi. Sehingga preferensi individu dalam menggunakan jasa keuangan ditentukan oleh pengetahuan dan pemahaman, kemampuan atau keterampilan, serta keyakinan individu tersebut dalam memenuhi kebutuhan finansialnya yang disebut sebagai literasi keuangan. Menurut Chen dan Volpe (1998) literasi keuangan merupakan pengetahuan untuk mengelola keuangan (financial literacy is money management knowledge).

Menurut Lusardi, dkk (2009) Literasi keuangan merupakan kebutuhan dasar bagi setiap orang agar terhindar dari masalah keuangan dan bagaimana mengelola keuangan serta teknik dalam berinvestasi dengan tujuan mencapai kesejahteraan.

Menurut Widayati (2012) faktor-faktor yang mempengaruhi literasi keuangan yakni :

1. Jenis Kelamin

Nababan dan Sadalia (2012) menemukan bahwa laki-laki cenderung memiliki Literasi

Keuangan personal yang labih tinggi dibandingka perempuan.

2. Tempat Tinggal

Mahasiswa yang tinggal sendiri memiliki tingkat personal financial literasi lebih tinggi dibandingkan mahasiswa yang tinggal dengan orang tua. Hal ini kemungkinan disebabkan karena mahasiswa yang tinggal sendiri lebih mandiri dan sering terlibat langsung dengan 


\section{Jurnal Riset Akuntansi dan Bisnis}

Vol . 20, No. 1, 2020, hal. 23-37

ISSN 1693-7597 (Print), 2623-2650 (online)

Available online: http://jurnal.umsu.ac.id/index.php/akuntan

pengelolaan keuangan pribadinya, disbanding dengan mahasiwa yang tinggal dengan orang tua.

3. IPK (Indeks Prestasi Kumulatif)

Menurut Margaretha dan Pambudhhi (2015) menjelaskan semakin tinggi IPK mahasiswa, maka semakin baik dalam mengelola keuangan pribadinya atau memiliki keuangan yang lebih sehat (lebih baik).

4. Pendidikan Orang Tua

Tingkat pendidikan orang tua adalah modal untuk merawat dan memperhatikan akan kebutuhan anak, diharapkan semakin tinggi pendidikan orang tuanya maka akan semakin banyak pengetahuan yang berguna dalam merawat anaknya.

5. Tingkat Pendapatan Oramg Tua

Menurut Nababan dan Sadalia (2012) tingkat pendapatan orang tua adalah tingkat penghasilan yang diperoleh orang tua responded selama sebulan baik dari penerimaan gaji, upah, ataupun penerimaan hasil usaha.

Menurut Harsanto (2016) menjelaskan ada beberapa indikator yang dapat dijadikan patokan terkait literasi keuangan adalah sebagai berikut :

1. Seseorang harus mampu membuat surplus keuangannya, ini berhubungan dengan sejauh mana seseorang mampu menambah aset keuangan yang dimiliki.

2. Memahami dan mengetahui dengan jelas berapa yang harus ditabung dan di investasikan setiap bulannya.

3. Mengetahui produk-produk keuangan yang sesuai dengan profil dan latar belakang yang dimiliki.

\section{Inklusi Keuangan}

Pada hakikatnya Inklusi Keuangan adalah seluruh upaya yang bertujuan meniadakan segala bentuk hambatan terhadap akses masyarakat dalam memanfaatkan layanan jasa keuangan dengan biaya yang terjangkau.

Dalam peraturan OJK, keuangan inklusif didefinisikan sebagai ketersediaan akses pada berbagai lembaga, produk dan layanan jasa keuangan sesuai dengan kebutuhan dan kemampuan masyarakat dalam rangka meningkatkan kesejahteraan masyarakat (POJK, 2016).

Untuk mewujudkan program inklusi keuangan yang berkesinambungan diperlukan koordinasi antara Bank Indonesia dengan kementerian dan insitusi terkait dalam rangka pengembangan, penetapan prioritas dan pelaksanaan program, serta pelaksanaan monitoring dan evaluasi program. Dengan koordinasi yang baik diharapkan tujuan peningkatan akses masyarakat kepada layanan keuangan dapat tercapai.

Menurut Nasution, dkk (2013) terdapat beberapa faktor yang dapat mempengaruhi inklusi keuangan, yakni :

1. Penetrasi Perbankan

Semakin banyak penggunanya maka semakin baik, karena itu sistem keuangan diharapkan dapat menjangkau secara luas di antara penggunanya. Salah satu indikator penetrasi perbankan adalah proporsi populasi yang memiliki rekening dibank.

2. Ketersediaan Jasa Keuangan 


\section{Jurnal Riset Akuntansi dan Bisnis \\ Vol . 20, No. 1, 2020, hal. 23-37 \\ ISSN 1693-7597 (Print), 2623-2650 (online) \\ Available online: http://jurnal.umsu.ac.id/index.php/akuntan}

Jasa keuangan harus tersedia bagi semua pengguna, dalam suatu sistem keuangan yang inklusif. Ukuran ketersediaan ini adalah jumlah outlet (kantor cabang, ATM, dan lain lain). Ketersediaan jasa dapat dilihat dari jumlah cabang lembaga keuangan atau jumlah ATM.

3. Penggunaan Jasa Perbankan

Banyak alasan mengapa sekelompok orang masih belum memanfaatkan keberadaan jasa keuangan meskipun mereka memiliki akses terhadap jasa keuangan. Di antaranya, jauhnya outlet bank dari tempat kediaman atau aktivitas sehari-hari, pengalaman buruk yang melibatkan penyedia jasa. Oleh sebab itu, memiliki rekening tidak cukup untuk menunjukkan sistem keuangan yang inklusif, namun masyarakat juga bisa menggunakannya. Kegunaan tersebut di antaranya dapat dalam bentuk kredit, deposit, pembayaran, remitansi, dan transfer.

4. Jumlah Pengguna Internet dan telpon Seluler

Perkembangan telepon seluler maupun internet menunjukkan adanya kemajuan dalam teknologi. Kedua teknologi ini dapat memperluas informasi dan mengurangi hambatan jarak dan waktu. Telepon seluler dan internet dimanfaatkan layanan jasa keuangan untuk memperluas akses pelayanan.

Sementara untuk indikator inklusi keuangan dikelompokkan dalam tiga jenis dimensi (OJK,2016) sebagai berikut :

1. Akses, yaitu kemampuan untuk menggunakan layanan keuangan formal dalam hal keterjangkauan secara fisik dan biaya, yang diukur dengan indikator :

a) Jumlah kantor layanan keuangan formal per 100.000 penduduk dewasa.

b) Jumlah mesin ATM/EDC/Mobile POS lainnya per 1.000 penduduk dewasa.

c) Jumlah agen layanan keuangan per 100.000 penduduk dewasa.

2. Penggunaan, yaitu penggunaan aktual atas layanan dan produk keuangan, yang diukur dengan indikator :

a) Jumlah rekening tabungan di lembaga keuangan formal per 1.000 penduduk;

b) Jumlah rekening kredit di lembaga keuangan formal per 1.000 penduduk dewasa;

c) Jumlah rekening uang elektronik terdaftar (registered) pada agen Layanan Keuangan Digital (LKD);

d) Persentase kredit/pembiayaan UMKM terhadap total kredit/pembiayaan di lembaga keuangan formal;

e) Jumlah rekening kredit UMKM di lembaga keuangan formal per 1.000 penduduk dewasa;

f) Persentase peningkatan jumlah lahan yang bersertifikat; dan

g) Jumlah penerima bantuan sosial yang disalurkan secara nontunai.

3. Kualitas, yaitu tingkat pemenuhan kebutuhan atas produk dan layanan keuangan yang dapat memenuhi kebutuhan masyarakat, yang diukur dengan indikator :

a) Indeks literasi keuangan

b) Jumlah pengaduan layanan keuangan dan

c) Persentase penyelesaian layanan pengaduan.

\section{Minat}

Zusnani (2013) mengartikan minat adalah satu perhatian yang kuat dan mendalam disertai dengan perasaan senang terhadap suatu kegiatan sehingga mengarahkan seseorang untuk melakukan kegiatan tersebut dengan kemauan sendiri. 


\section{Jurnal Riset Akuntansi dan Bisnis \\ Vol . 20, No. 1, 2020, hal. 23-37 \\ ISSN 1693-7597 (Print), 2623-2650 (online) \\ Available online: http://jurnal.umsu.ac.id/index.php/akuntan}

Sehingga minat merupakan sikap seseorang yang mempunyai keinginan yang tinggi terhadap sesuatu atau suatu rasa kemauan yang kuat untuk melakukan suatu hal untuk mencapai tujuan tertentu.

Menurut (Taufani, 2008) ada tiga faktor yang mendasari timbulnya minat yaitu :

a. Faktor dorongan dalam, yaitu dorongan dari individu itu sendiri, sehingga timbul minat untuk melakukan aktivitas atau tindakan tertentu untuk memenuhinya.

b. Faktor motivasi sosial, yaitu faktor untuk melakukan suatu aktivitas agar dapat diterima dan diakui oleh lingkungannya. Minat ini merupkan semacam kompromi pihak individu dengan lingkungan sosialnya.

c. Emosi (gejala perasaan) : kecenderungan untuk memiliki perasaan yang khas bila berhadapan dengan objek tertentu dalam lingkungannya.

Menurut Abror (1989) bahwa minat mengandung tiga indikator yang dijadikan acuan terbentuknya minat :

a. Kognisi (mengenal) : Minat itu didahului oleh pengetahuan dan informasi mengenai obyek yang dituju oleh minat tersebut.

b. Emosi (perasaan) : Unsur emosi, karena dalam partisipasi atau pengalaman itu disertai dengan perasaan tertentu (biasanya perasaan senang).

c. Konasi (kehendak) : merupakan kelanjutan dari kedua unsur tersebut yaitu yang diwujudkan dalam bentuk kemauan dan hasrat untuk melakukansuatu kegiatan, termasuk kegiatan yang diselenggarakan disekolah.

\section{Lembaga Keuangan Syariah}

Lembaga keuangan adalah setiap perusahaan yang bergerak dibidang keuangan, dengan menghimpun dana, menyalurkan dana, atau kedua-duanya (Muljono, 2015).

Menurut Soemitra (2009) Lembaga keuangan syariah merupakan suatu badan usaha yang menjalankan sistem berdasarkan prinsip-prinsipyang ditetapkan dalam hukum islam. Secara umum terdapat beberapa prinsip lembaga keuangan syariah yang dianut berdasarkan hukum islam, diantaranya : Mudharabah, Musyarakah, Wadiah, Al Murabahah, Salam, Istishna, Ijarah, Qardhrahn Hawalah/Hiwalah, Wakalah.

Lembaga keuangan syariah secara esensial berbeda dengan lembaga keuangan konvensional, baik dalam tujuan, mekanisme, kekuatan, ruang lingkup, serta tanggung jawabnya. Setiap institusi dalam lembaga keuangan syariah menjadi bagian integral dari sistem syariah (Muljono, 2015).

\section{HIPOTESIS}

Hipotesis merupakan jawaban sementara terhadap rumusan masalah, oleh karena itu rumusan masalah penelitian biasanya disusun dalam bentuk kalimat pertanyaan. Dikatakan sementara, karena jawaban yang diberikan baru didasarkan pada teori yang relevan, belum didasarkan pada fakta-fakta empiris yang diperoleh melalui pengumpulan data. Hipotesis dalam penelitian ini dapat dijabarkan sebagai berikut:

Mengarah pada rumusan masalah, teori yang dikemukakan dalam penelitian-penelitian terdahulu yang telah dilaksanakan maka hipotesis yang diajukan dalam penelitian ini adalah :

1. Literasi Keuangan berpengaruh signifikan terhadap minat Mahasiswa Manajemen Universitas Muhammadiyah Sumatera Utara dalam Menggunakan Lembaga Keuangan Syariah. 


\section{Jurnal Riset Akuntansi dan Bisnis \\ Vol . 20, No. 1, 2020, hal. 23-37 \\ ISSN 1693-7597 (Print), 2623-2650 (online) \\ Available online: http://jurnal.umsu.ac.id/index.php/akuntan}

2. Inklusi keuangan berpengaruh signifikan terhadap minat Mahasiswa Manajemen Universitas Muhammadiyah Sumatera Utara dalam menggunakan lembaga keuangan syariah.

3. Literasi keuangan dan inklusi keuangan secara bersama-sama berpengaruh signifikan terhadap minat Mahasiswa Manajemen Universitas Muhammadiyah Sumatera Utara dalam menggunakan lembaga keuangan syariah.

Hipotesis tersebut dapat digambarkan melalui kerangka konseptual sebagai berikut:

\section{METODE PENELITIAN}

Pendekatan yang digunakan dalam penelitian ini adalah pendekatan kuantitatif. Pendekatan kuantitatif merupakan penelitian yang menggunakan data kuantitatif (data yang berbentuk angka/ data yang diangkakan).

Sementara, jenis penelitian yang digunakan dalam penelitian ini adalah penelitian assosiatif, yang berarti penelitian yang berusaha mencari hubungan antara satu variabel dengan variabel lainnya. Hubungan bisa simetris, kasual atau interaktif. Populasi dalam penelitian ini adalah seluruh mahasiswa Ekonomi Jurusan Manajemen UMSU semester 6 (enam). Dari populasi Mahasiswa Manajemen semester 6 (enam) Universitas Muhammadiyah Sumatera Utara sebanyak 548 populasi yang kemudian menghasilkan sebanyak 231 sampel, karena teknik pengambilan penelitian ini menggunakan simple random sampling maka penelitian ini hanya akan mengambil sampel sebanyak 100 jiwa.

Teknik pengumpulan data yang digunakan adalah :

1. Kuisioner (angket)

Angket merupakan teknik pengumpulan data yang dilakukan dengan cara memberi seperangkat pertanyaan atau pernyataan tertulis kepada responden untuk dijawabnya Sugiyono (2018).

2. Wawancara

Wawancara digunakan sebagai teknik pengumpulan data apabila peniliti ingin melakukan studi pendahuluan untuk menemukan permasalahan yang harus diteliti dan juga apabila peneliti ingin mengetahui hal-hal dari responden yang lebih mendalam dan jumlah respondennya sedikit/lebih kecil (Sugiyono,2018).

3. Studi Dokumentasi

Studi dokumentasi adalah mengumpulkan data dengan cara melihat atau menilai data-data historis masa lalu, (Sugiyono, 2018).

Teknik analisis data yang digunakan dalam penelitian ini adalah regresi linear berganda dengan persamaan :

Sumber : Sugiyono(2018)

$$
Y=a+b^{1} X^{1}+b^{2} X^{2}
$$

Keterangan :

Y : Minat dalam menggunakan lembaga keuangan syariah

$\mathrm{X} 1$ : Literasi keuangan

X2 : Inklusi Keuangan

A : Konstanta

b1 dan b2 : besaran koefisien regresi dari masing-masing variabel 


\section{Jurnal Riset Akuntansi dan Bisnis}

Vol . 20, No. 1, 2020, hal. 23-37

ISSN 1693-7597 (Print), 2623-2650 (online)

Available online: http://jurnal.umsu.ac.id/index.php/akuntan

\section{Definisi Operasional}

Berdasarkan pada masalah dan hipotesis yang akan diuji, maka variabel-variabel yang akan diteliti adalah variabel independen (bebas) dan variabel dependen (terikat), sebagai berikut :

1. Variabel bebas (independent variable) dengan simbol X Merupakan variabel yang mempengaruhi atau yang menyebabkan pengaruh pada minat mahasiswa ekonomi jurursan manajemen UMSU dalam menggunakan Lembaga keuangan Syariah yang terdiri dari literasi keuangan (X1) dan inklusif keuangan (X2).

a. Literasi keuangan (X1)

Literasi Keuangan adalah suatu pemahaman dan keterampilan mahasiswa dalam menggunakan layananan jasa keuangan syariah.

b. Inklusi Keuangan adalah akses yang tersedia bagi mahasiswa untuk menggunakan layanan jasa keuangan syariah.

2. Variabel terikat (dependent variable) Y merupakan variabel yang dipengaruhi oleh variabel dependen, variable dependen dalam penelitian ini adalah minat mahasiswa ekonomi jurusan manajemen Umsu dalam menggunakan Lembaga Keuangan Syariah.

\section{HASIL PENELITIAN DAN PEMBAHASAN Analasis Regresi Linear Berganda}

Analisis data dalam penelitian ini menggunakan analisis regresi berganda. Dalam penelitian ini terdapat dua variabel independen, yaitu literasi keuangan dan Inklusi keuangan serta satu variabel dependen yaitu Minat Mahasiswa dalam menggunakan lembaga keuangan syariah sebagi berikut :

Tabel 1. Hasil Uji Regresi Linear Berganda

Coefficients $^{\mathrm{a}}$

\begin{tabular}{|c|c|c|c|c|c|}
\hline \multirow[t]{2}{*}{ Model } & \multicolumn{2}{|c|}{ Unstandardized Coefficients } & $\begin{array}{c}\text { Standardized } \\
\text { Coefficients }\end{array}$ & \multirow[b]{2}{*}{$\mathrm{T}$} & \multirow[b]{2}{*}{ Sig. } \\
\hline & B & Std. Error & Beta & & \\
\hline (Constant) & 5,819 & 3,872 & & 1,503 &, 136 \\
\hline Literasi Keuangan & ,425 & 117 & ,319 & 3,631 &, 000 \\
\hline Inklusi Keuangan & ,894 & , 176 & 447 & 5,090 & , 000 \\
\hline
\end{tabular}

Sumber : Data diolah (2020)

Berdasarkan perhitungan yang dilakukan menggunakan SPSS diatas, maka dapat dilihat persamaan regresi berganda sebagai berikut :

$$
\mathrm{Y}=5,819+0,425 \text { literasikeuangan }+0,894 \text { Inklusikeuangan }
$$

Berdasarkan persamaan regresi tersebut dianalisis pengaruh Literasi keuangan dan inklusi keuangan terhadap minat mahasiswa dalam menggunakan lembaga keuangan syariah sebagai berikut :

a) 5,819 menunjukkan bahwa apabila variabel literasi keuangan dan inklusi keuangan adalah 0 (nol) maka nilai minat dalam menggunakan lembaga keuangan syariah sebesar 5,819.

b) 0,425 menunjukkan bahwa apabila variabel literasi keuangan ditingkatkan $100 \%$ maka nilai minat mahasiswa dalam menggunakan lembaga keuangan syariah akan bertambah sebanyak $42,5 \%$. 


\section{Jurnal Riset Akuntansi dan Bisnis}

Vol . 20, No. 1, 2020, hal. 23-37

ISSN 1693-7597 (Print), 2623-2650 (online)

Available online: http://jurnal.umsu.ac.id/index.php/akuntan

c) 0,894 menunjukkan bahwa apabila variabel inklusi keuangan ditingkatkan $100 \%$ maka nilai minat mahasiswa dalam menggunakan lembaga keuangan syariah akan bertambah sebanyak $89,4 \%$.

\section{Pengujian Hipotesis}

\section{a. Pengujian Secara Parsial}

Pengujian pengaruh variabel-variabel bebas $(\mathrm{X})$ terhadap variabel terikat $(\mathrm{Y})$ :

Tabel 3. Hasil Uji Parsial (Uji t)

Coefficients $^{\mathrm{a}}$

\begin{tabular}{|c|c|c|c|c|c|}
\hline \multirow[t]{2}{*}{ Model } & \multicolumn{2}{|c|}{ Unstandardized Coefficients } & $\begin{array}{c}\text { Standardized } \\
\text { Coefficients }\end{array}$ & & \\
\hline & B & Std. Error & Beta & $t$ & Sig. \\
\hline (Constant) & 5,819 & 3,872 & & 1,503 &, 136 \\
\hline Literasi Keuangan & ,425 & 117 & ,319 & 3,631 &, 000 \\
\hline Inklusi Keuangan & 894 & 176 & 447 & 5,090 & , 000 \\
\hline
\end{tabular}

Berdasarkan hasil pengujian yang dilakukan secara parsial Literasi keuangan terhadap Minat Mahasiswa dalam menggunakan lembaga keuangan syariah diperoleh thitung 3,631 sedangkan tabel sebesar 1,984 dan nilai signifikasi 0,000 <0,05, dapat disimpulkan bahwa $\mathrm{H}_{0}$ ditolak yang berarti Literasi Keuangan berpengaruh positif dan signifikan terhadap Minat Mahasiswa Manajemen Umsu Dalam Menggunakan Lembaga Keuangan Syariah.

Berdasarkan hasil pengujian ini juga secara parsial Inklusi keuangan terhadap Minat Mahasiswa dalam Menggunakan Lembaga Keuangan syariah diperoleh thitung 5,090 sedangkan ttabel sebesar 1,984 dan nilai signifikasi $0,000<0,05$, hal ini dapat disimpulkan bahwa Ho ditolak, yang berarti Inklusi Keuangan berpengaruh positif dan signifikan terhadap Minat Mahasiswa Dalam Menggunakan Lembaga Keuangan Syariah.

\section{b. Pengujian Secara Simultan}

Untuk menguji pengaruh literasi keuangan dan inklusi keuangan secara simultan terhadap minat mahasiswa dalam menggunakan lembaga keuangan syariah maka dalam penelitian ini menggunakan uji F melalui program SPSS dan berikut adalah hasil pengujiannya :

Tabel 4. Uji Signifikansi Simultan (Uji f) ANOVA $^{\text {b }}$

\begin{tabular}{|ll|c|r|r|r|l|}
\hline Model & & Sum of Squares & Df & Mean Square & $\mathrm{F}$ & Sig. \\
\hline 1 & Regression & 1078,784 & 2 & 539,392 & 39,098 &, $000^{\mathrm{a}}$ \\
& Residual & 1338,216 & 97 & 13,796 & & \\
& Total & 2417,000 & 99 & & & \\
\hline
\end{tabular}

a. Predictors: (Constant), Inklusi Keuangan, Literasi Keuangan

b. Dependent Variable: Minat dalam menggunakan Lembaga Keuangan Syariah

Uji F diatas bertujuan untuk menguji hipotesis statistik, maka dilakukan uji F pada tingkat $\alpha=0,05$, nilai Fhitung untuk $n=100$ adalah sebagai berikut :

$$
\begin{aligned}
\text { Fhitung } & =\mathrm{n}-\mathrm{k}-1 \\
& =100-2-1=97 \\
\text { Fhitung } & =39,098 \\
\text { Ftabel } & =3,09
\end{aligned}
$$




\section{Jurnal Riset Akuntansi dan Bisnis \\ Vol . 20, No. 1, 2020, hal. 23-37 \\ ISSN 1693-7597 (Print), 2623-2650 (online) \\ Available online: http://jurnal.umsu.ac.id/index.php/akuntan}

Bedasarkan pengujian serta simultan pengaruh antara literasi keuangan dan inklusi keuangan diperoleh nilai Fhitung sebesar 39,098 > Ftabel 3,09 dan nilai signifikan sebesar 0,000 dimana lebih kecil dari 0,05. Dari hasil tersebut dapat disimpulkan bahwa $\mathrm{H}_{0}$ ditolak dan $\mathrm{H \alpha}$ diterima. Hal ini berarti menunjukkan adanya pengaruh signifikan literasi keuangan dan inklusi keuanagn terhadap minat mahasiswa dalam menggunakan lembaga keuangan syariah.

\section{c. Koefisien Determinasi}

Koefisien determinasi $\left(\mathrm{R}^{2}\right)$ berfungsi untuk melihat sejauh mana keseluruhan variabel independen dapat menjelaskan variabel dependen.

Tabel 5. Hasil Koefisien Determinasi

\begin{tabular}{|l|c|r|r|r|r|}
\multicolumn{7}{|c|}{ Model Summary $^{\mathbf{b}}$} \\
\hline 1 & $\mathrm{R}$ & $\begin{array}{c}\mathrm{R} \\
\text { Square }\end{array}$ & $\begin{array}{c}\text { Adjusted } \mathrm{R} \\
\text { Square }\end{array}$ & $\begin{array}{c}\text { Std. Error } \\
\text { of the } \\
\text { Estimate }\end{array}$ & Durbin-Watson \\
\hline
\end{tabular}

a. Predictors: (Constant), Inklusi Keuangan, Literasi Keuangan

b. Dependent Variable: Minat dalam menggunakan Lembaga Keuangan Syariah

Berdasarkan hasil uji Determinasi pada tabel IV. 17 dapat dilihat bahwa nilai R adalah 0,435 . Artinya adalah bahwa variabel independen (literasi keuangan dan inklusi keuangan) dapat menerangkan variabilitas hanya sebesar 43,5\% dari variabel dependen (minat mahasiswa ekonomi dan bisnis jurusan manajemen dalam menggunakan lembaga keuangan syariah, sedangkan sisanya 56,5\% diterangkan oleh variabel lain yang tidak diteliti.

\section{PEMBAHASAN}

\section{Pengaruh Literasi Keuangan Terhadap Minat Mahasiswa Dalam Menggunakan Lembaga Keuangan Syariah}

Berdasarkan hasil uji t yang dilakukan secara parsial Literasi keuangan terhadap Minat Mahasiswa dalam menggunakan lembaga keuangan syariah diperoleh thitung 3,631 sedangkan tabel sebesar 1,984 dan nilai signifikasi $0,000<0,05$, dapat disimpulkan bahwa $\mathrm{H}_{0}$ ditolak yang berarti literasi keuangan berpengaruh positif dan signifikan terhadap minat mahasiswa manajemen umsu dalam menggunakan lembaga keuangan syariah.

Berdasarkan hasil uji t yang telah dilakukan oleh peneliti, literasi keuangan memiliki pengaruh positif dan signifikan terhadap minat mahasiswa ekonomi dan bisnis jurusan manaajemen dalam menggunakan lembaga keuangan syariah, ini dapat di buktikan melalui jawaban responden yang setuju dengan pernyataan mengenai pengetahuan keuangan dapat membantu saya berinvestasi menggunakan produk keuangan syariah bagi masa depan yakni sebanyak 52 orang atau dengan persentase 52\%. Adapun jawaban mengenai membayar tagihan tepat waktu (listrik, air dll) menggunakan lembaga keuangan syariah mayoritas responden menjawab setuju yakni dengan persentase sebanyak 38\%. Untuk jawaban mengenai pernyataan mencatat pengeluaran (harian,bulanan) menjadi rutinitas saya setiap hari, responden yang menjawab setuju sebanyak 46\%. Pernyataan mengenai membandingkan harga antar took/swalayan atau supermarket 


\section{Jurnal Riset Akuntansi dan Bisnis \\ Vol . 20, No. 1, 2020, hal. 23-37 \\ ISSN 1693-7597 (Print), 2623-2650 (online) \\ Available online: http://jurnal.umsu.ac.id/index.php/akuntan}

sebelum melakukan keputusan pembelian mayoritas responden menjawab sangat setuju dengan persentase sebanyak $60 \%$. Untuk pernyataan mengenai saya akan menyimpan uang dalam lembaga keuangan syariah untuk kebutuhan tidak terduga, mayoritas dijawab setuju oleh responden dengan persentase sebanyak 37\%. Sedangkan untuk pernyataan mengenai tentang membuat anggaran belanja secara rutin responden menjawab setuju dengan persentase sebanyak 54\% dan untuk jawaban pernyataan mengenai menabung secara rutin pada lembaga keuangan syariah mayoritas dijawab setuju oleh responden dengan persenatase sebanyak $44 \%$.

Berdasarkan penelitian yang telah dilakukan, berikut pengukuran literasi keuangan pada Mahasiswa Ekonomi dan Bisnis Jurusan Manajemen UMSU :

a) Pada Aspek Pengetahuan Keuangan, rata-rata jawaban responden yang benar adalah 75,33\% yang berarti termasuk dalam kategori sedang.

b) Pada Aspek Tabungan Atau Investasi, rata-rata jawaban responden yang menjawab benar adalah $80,33 \%$ yang berarti masuk dalam kategori tinggi.

c) Pada Aspek Asuransi, rata-rata jawaban responden yang menjawab pernyataan dengan benar adalah 78,66\% yang berarti masuk dalam kategori sedang.

d) Pada aspek Investasi, rata-rata jawaban responden yang menjawab benar adalah $68,33 \%$ yang berarti masuk dalam kategori sedang.

Penelitian ini di dukung oleh Kardinal (2017) yang menemukan bahwa tingkat pengetahuan mahasiswa di STIE Multi Data Palembang sudah cukup baik, ini terlihat dari beberapa kategori yang ditetapkan, dari 243 responden yang ditanyakan, persentase yang masuk dalam kategori rendah hanya 8 responden atau 3,3\%.

Herdianti (2017) dalam penelitiannya menunjukkan bahwa tingkat literasi keuangan syariah mahasiswa non ekonomi pada kategori sedang dengan persentase sebesar 68,7\%. Variabel independen secara simultan berpengaruh signifikan terhadap minat. Secara parsial pengetahuan keuangan dasar syariah dan tabungan syariah tidak berpengaruh terhadap minat sedangkan investasi syariah, asuransi syariah, pengetahuan lembaga keuangan syariah dan pengetahuan produk lembaga keuangan syariah berpengaruh signifikan.

\section{Pengaruh Inklusi Keuangan Terhadap Minat Mahasiswa Dalam Menggunakan Lembaga Keuangan Syariah}

Pada hakikatnya inklusi keuangan adalah seluruh upaya yang bertujuan meniadakan segala bentuk hambatan terhadap akses masyarakat dalam memanfaatkan layanan jasa keuangan dengan biaya yang terjangkau. World Bank (2014b) mendefinisikan inklusi keuangan sebagai proporsi individu dan perusahaan yang menggunakan produk dan jasa keuangan.

Berdasarkan hasil uji t yang dilakukan secara parsial Inklusi keuangan terhadap Minat Mahasiswa dalam Menggunakan Lembaga Keuangan syariah diperoleh thitung 5,090 sedangkan tabel sebesar 1,984 dan nilai signifikasi 0,000 <0,05, hal ini dapat disimpulkan bahwa $\mathrm{Ho}$ ditolak, yang berarti Inklusi Keuangan berpengaruh positif dan signifikan terhadap Minat Mahasiswa Dalam Menggunakan Lembaga Keuangan Syaraih.

Hal ini berarti dengan semakin mudahnya akses dan keberagaman produk lembaga keuangan syariah menjadikan Minat Mahasiswa Ekonomi Jurusan Ekonomi UMSU cukup besar dalam menggunakan lembaga keuangan syariah.

Menurut OJK (2016) kegiatan keuangan Inklusif menjadi salah satu agenda penting dalam dunia Internasional. Bahkan di Indonesia sendiri Strategi Nasional Keuangan Inklusif 


\section{Jurnal Riset Akuntansi dan Bisnis \\ Vol . 20, No. 1, 2020, hal. 23-37 \\ ISSN 1693-7597 (Print), 2623-2650 (online) \\ Available online: http://jurnal.umsu.ac.id/index.php/akuntan}

(SNKI) telah diluncurkan pada tanggal 18 November 2016. Program SNKI ini bertujuan agar diharapkan seluruh masyarkat termasuk mahasiswa dapat dengan mudah dalam mengakses layanan lembaga keuangan sesuai dengan kebutuhan. Tidak hanya mempermudah akses lembaga keuangan konvensional saja namun juga lembaga keuangan syariah.

Inklusif keuangan dapat diwujudkan melalui akses masyarakat terhadap layanan keuangan sehingga dapat meningkatkan kemampuan ekonomi dan pada akhirnya membuka jalan untuk keluar dari kemiskinan serta mengurangi kesenjangan ekonomi. Akses yang lebih luas terhadap layanan keuangan merupakan hal penting dalam upaya peningkatan partisipasi seluruh lapisan masyarakat dalam perekonomian.

Berdasarkan hasil penelitian yang telah dilakukan, peneliti menyimpulkan bahwa terdapat pengaruh yang signifikan antara Inklusi keuangan terhadap minat mahasiswa Ekonomi dan Bisnis Jurusan Manajemen dalam menggunakan lembaga keuangan syariah. Hal ini dapat di buktikan melalui jawaban responden yang menyatakan setuju terhadap pernyataan tentang layanan jasa keuangan syariah yang saat ini saya gunakan mudah untuk di akses, dengan persentase sebanyak 58\%. Untuk pernyataan mengenai fasilitas lembaga keuangan syariah yang diberikan mampu memenuhi kebutuhan saya dalam mengelola keuangan saya, mayoritas dijawab setuju oleh responden yakni sebanyak 59\%. Sementara untuk pernyataan mengenai pemerataan pendapatan memperluas kesempatan masyarakat dalam menjangkau akases perbankan, mayoritas dijawab setuju oleh responden dengan persentase sebanyak $62 \%$. Pernyataan mengenai ketersediaan jasa keuangan penting agar masyarakat dapat dengan mudah menjangkaunya, mayoritas dijawab setuju oleh responden dengan persentase sebanyak $65 \%$. Untuk pernyataan mengenai internet dapat dimanfaatkan oleh layanan jasa keuangan untuk memperluas akses pelayanan, mayoritas dijawab oleh responden yakni sebanyak $53 \%$ dan untuk pernyataan sebaiknya lembaga keuangan membuat layanan pengaduan keuangan, mayoritas dijawab oleh responden dengan persentase sebanyak $56 \%$

Penelitian ini di dukung oleh penelitian Umar (2017). Hasil penelitian menghitung dan menganalisis Indeks Inklusi Keuangan Syariah (ISFI) yang mencakup tiga ukuran; aksesibilitas, ketersediaan, dan penggunaan layanan perbankan syariah. Menggunakan tahunan data di tingkat provinsi di Indonesia selama periode 2010-2015, peneilitian ini menemukan bahwa Indeks Inklusi Keuangan Syariah umumnya rendah dan Bangka Belitung adalah provinsi yang paling inklusif secara finansial dari Indonesia. Selanjutnya, hasil menunjukkan bahwa Indeks Inklusi Keuangan Syariah positif berkorelasi dengan Indeks Pembangunan Manusia. Kesimpulan ini menyarankan promosi Keuangan Syariah Inklusi menjadi prioritas kebijakan di Indonesia untuk mencapai tujuan utama pertumbuhan inklusif, kesejahteraan dan pertumbuhan ekonomi.

Penelitian ini juga didukung dengan penelitian yang dilakukan oleh Ardiana (2016), hasil penelitian inklusif keuangan secara parsial berpengaruh positif dan signifikan terhadap perilaku menabung siswa SMK sekota Kediri. Berdasarkan uji yang dilakukan yaitu bahwa inklusif keuangan berpengaruh positif dan signifikan terhadap perilaku menabung siswa SMK sekota Kediri.

\section{Pengaruh Literasi Keuangan Dan Inklusi Keuangan Terhadap Minat Mahasiswa Ekonomi Jurusan Manajemen UMSU dalam Menggunakan lembaga Keuangan Syariah}

Zusnani (2013) mengartikan minat adalah satu perhatian yang kuat dan mendalam disertai dengan perasaan senang terhadap suatu kegiatan sehingga mengarahkan seseorang untuk melakukan kegiatan tersebut dengan kemauan sendiri. Sehingga minat dapat diartikan sebagai 


\section{Jurnal Riset Akuntansi dan Bisnis}

Vol . 20, No. 1, 2020, hal. 23-37

ISSN 1693-7597 (Print), 2623-2650 (online)

Available online: http://jurnal.umsu.ac.id/index.php/akuntan

sikap seseorang yang mempunyai keinginan yang tinggi terhadap sesuatu atau suatu rasa kemauan yang kuat untuk melakukan suatu hal untuk mencapai tujuan tertentu.

Bedasarkan pengujian serta simultan pengaruh antara literasi keuangan dan inklusi keuangan diperoleh nilai Fhitung sebesar 39,098 > Ftabel 3,09 dan nilai signifikan sebesar 0,0000 dimana lebih kecil dari 0,05. Dari hasil tersebut dapat disimpulkan bahwa $\mathrm{Ho}$ ditolak dan $\mathrm{H} \alpha$ diterima. Hal ini berarti menunjukkan adanya pengaruh signifikan literasi keuangan dan inklusi keuangan terhadap minat mahasiswa dalam menggunakan lembaga keuangan syariah.Ini berarti dengan adanya pengetahuan dan keyakinan terhadap lembaga keuangan syariah serta didukung oleh kemudahan akses lembaga keuangan syariah menjadikan mahasiswa berminat dalam menggunakan lembaga keuangan syariah.

Berdasarkan hasil penelitian yang telah dilakukan, peneliti menyimpulkan bahwa literasi keuangan dan inklusi keuangan memilki pengaruh signifikan terhadap minat mahasiswa ekonomi dan bisnis jurusan manajemen dalam menggunakan lembaga keuangan syariah, ini dapat dibuktikan melalui pernyataan-pernyataan yang telah dilakukan oleh peneliti kepada responden melalui kuisioner yang telah di sebar ke 100 mahasiswa manajemen semester 6 (enam). Untuk pernyataan mengenai sejak dikeluarkannya fatwa MUI tentang keharaman riba, saya segera beralih menabung di bank syariah, mayoritas responden menjawab setuju dengan persentase sebanyak $48 \%$. Sementara untuk pernyataan mengenai lembaga keuangan syariah melaksanakan prinsip-prinsip islam dalam setiap praktik transaksinya, mayoritas dijawab setuju oleh responden yakni sebanyak 58\%. Untuk pernyataan mengenai lembaga keuangan syariah tidak mengandung unsur riba, mayoritas dijawab setuju yakni sebanyak $42 \%$. Pernyataan mengenai menabung dilembaga keuangan syariah karena letaknya yang mudah dijangkau mayoritas dijawab setuju oleh responden dengan persentase sebanyak 51\%. Sementara untuk pernyataan tentang layanan keuangan syariah sangat baik, responden yang memilih jawaban setuju sebanyak $71 \%$. Untuk jawaban mengenai saya menggunakan lembaga keuangan syariah karena menggunakan sistem bagi hasil, mayoritas dijawab sangat setuju oleh responden dengan persentase sebanyak 59\%. Adapun jawaban responden mengenai produk-produk lembaga keuangan syariah sesuai dengan syariat islam, mayoritas responden menjawab setuju sebanyak $52 \%$. Untuk pernyataan tentang saya menabung di bank syariah karena rendahnya minimal setoran awal, mayoritas dijawab setuju oleh responden denga persenatase sebanyak $40 \%$. Adapun jawaban untu pernyataan lembaga keuangan syariah memiliki kredibilitas yang baik, mayoritas dijawab setuju oleh responden yakni sebanyak $60 \%$ dan untuk pernyataan mengenai, dengan menggunakan lembaga keuangan syariah, maka saya akan terhindar dari riba, mayoritas dijawab sangat setuju oleh responden dengan persentase sebanyak $34 \%$.

Beradasarkan dengan penelitian yang telah dilakukan dapat disimpulkan bahwa literasi keuangan dan inklusi keuangan memiliki hubungan yang erat terhadap minat seseorang dalam menggunakan lembaga keuangan syariah. Literasi keuangan sangat perlu diterapkan dalam diri seseorang sebelum mereka memanfaatkan produk dan layanan jasa keuangan syariah. Sementara Inklusi Keuangan dibutuhkan untuk menunjang berbagai macam kebutuhan yang diperlukan inidvidu akan lembaga keuangan syariah.

\section{KESIMPULAN}

Dari pembahasan yang sudah dilakukan diatas maka peneliti dapat menarik kesimpulan sebagai berikut : 


\section{Jurnal Riset Akuntansi dan Bisnis}

Vol . 20, No. 1, 2020, hal. 23-37

ISSN 1693-7597 (Print), 2623-2650 (online)

Available online: http://jurnal.umsu.ac.id/index.php/akuntan

1. Secara parsial literasi keuangan berpengaruh positif dan signifikan terhadap minat mahasiswan ekonomi jurusan manajemen UMSU dalam menggunakan lembaga keuangan syariah.

2. Secara parsial inklusi keuangan berpengaruh positif dan signifikan terhadap minat mahasiswan ekonomi jurusan manajemen UMSU dalam menggunakan lembaga keuangan syariah.

3. Secara simultan literasi keuangan dan inklusi keuangan berpengaruh positif dan signifikan terhadap minat mahasiswan ekonomi jurusan manajemen UMSU dalam menggunakan lembaga keuangan syariah.

\section{DAFTAR PUSTAKA}

Alpi, M.F. (2018). Pengaruh Debt To Equity Ratio, Inventory Turn Over, Dan Current Ratio Terhadap Return On Equity Pada Perusahaan Sektor Farmasi Yang Terdaftar Di Bursa Efek Indonesia. Prosiding. The National Conferences Management and Business (NCMAB) 2018 "Pemberdayaan dan Penguatan Daya Saing Bisnis Dalam Era Digital”. ISSN: 2621 - 1572. p: 158-175.

Ardiana, Meta. (2016). Kontrol Diri, Pendidikan Pengelolaan Keuangan Keluarga, Pengetahuan Inklusi Keuangan Siswa Pengaruhnya Terhadap Perilaku Menabung Siswa Smk SeKota Kediri. Jurnal Ekonomi Pendidikan dan Kewirausahaan. 4 (1),-59-63.

Chen, Haiyang dan Volpe, Ronald P. (1998). An Analysis of Personal Financial Literacy Among College Students. Journal Financial Services Review. 7(2),-107-128.

Fitriastuti, Triana, Sari, Dhina Mustika, Purnamasari, Ike. (2015). Implementasi Keuangan Inklusif Bagi Masyarakat Perbatasan (Studi kasus pada Kutai timur, kabupaten kutai kartanegara dan kota samarinda, Kalimantan timur, Indonesia). SNEMA.-41-46.

Herdianti, Ika Fitri. (2017). Analisis Tingkat Literasi Keuangan Syariah Mahasiswa Serta Pengaruhnya Terhadap Minat Mahasiswa Menjadi Nasabah Pada Lembaga Keuangan Syariah.

Kardinal. (2017). Pengaruh Literasi Keuangan Terhadap Penggunaan Produk Keuangan pada Mahasiswa STIE Multi Data Palembang. Jurnal Ilmiah STIE MDP. 7 (1),-55-64.

Khrisna, Ayu, Rofaida, Rofi, Sari Maya. (2010). Analisis Tingkat Literasi Keuangan di Kalangan

Mahasiswa Dan Faktor-FaktorYang Mempengaruhinya. Proceedings of the $4^{\text {th }}$ International Conference on Teacher Education. -552-560.

Khusna, Himayatul. (2018). Pengaruh Literasi Keuangan Dan Inklusif Keuangan Terhadap Minat Mahasiswa Jurusan Ekonomi Syariah Institut Agama Islam Negeri Tulungagung Dalam Menggunakan Lembaga Keuangan Syariah.

Lusardi, Annamaria, Mitchell, Olivia S, Curto, Vilsa. (2009). Financial literacy among the young : Evidance and implications for consumer policy. NBER Working Paper. -1-33.

Muljono, Djoko. (2015) . Buku Pintar Akuntansi Perbankan Dan Lembaga Keuangan Syariah. Yogyakarta : ANDI.

Nasution, Lia Nazliana, Sari, Pipit Buana, Dwilita, Handriyani. (2013). Determinan Keuangan Inklusif Di Sumatera Utara, Indonesia. Jurnal Ekonomi dan studi pembangunan. 14 $(1),-58-66$. 


\section{Jurnal Riset Akuntansi dan Bisnis}

Vol . 20, No. 1, 2020, hal. 23-37

ISSN 1693-7597 (Print), 2623-2650 (online)

Available online: http://jurnal.umsu.ac.id/index.php/akuntan

Pulungan, Delyana Rahmawany, Febriaty, Hastina. (2018). Pengaruh Gaya Hidup Dan Literasi Keuangan Terhadap Perilaku Konsumtif Mahasiswa. Jurnal Riset Sains Manajemen. 2 (3),-103-110.

Soemitra, Andri. (2017). Bank dan Lembaga Keuangan Syariah. (Edisi Kedua). Depok :Penerbit Kencana.

Sugiyono. (2018). Metode penelitian Kuantitatif, kualitatif dan $R$ \& D. Bandung : Alfabeta. Umar, Azwar Iskandar. (2017). Index of Syariah Financial Inclusion in Indonesia. Jurnal Buletuin Ekonomi Moneter dan perbankan. 20 (1),-100-126.

Zusnani, Ida. (2013). Pendidikan Kepribadian Siswa SD-SMA. Jakarta Selatan : Tugu Publisher. Link :

Intisari.grid.id $>$ finance

www.kamriantiramli.wordpress.com/tag/faktor-faktor-yangmembangkitkanminat-belajar wWw.ojk.go.id 